\title{
The effect of educational intervention on the disease knowledge of diabetes mellitus patients ${ }^{1}$
}

\author{
Dalma Alves Pereira² \\ Nilce Maria da Silva Campos Costa $^{3}$ \\ Ana Luíza Lima Sousa ${ }^{4}$ \\ Paulo César Brandão Veiga Jardim ${ }^{5}$ \\ Cláudia Regina de Oliveira Zanini ${ }^{6}$
}

The prevention of diabetes and its complications is a challenge for the healthcare team. The aim of this study was to evaluate the effect of educational action on the disease knowledge of patients with type 2 diabetes. A randomized clinical trial was conducted with 62 patients registered in a service of reference in the treatment of hypertension in 2010. Data were collected through a questionnaire applied to the Intervention (IG) and Control (CG) groups at the beginning and at the end of the study. The IG participated in group educational activities, using problematization methodology. The results showed a significant increase in knowledge about diabetes in the patients of the IG, in all the topics $(p<0.05)$. In the $C G$, some changes were observed in knowledge, however, these were fewer when compared with the IG. In conclusion, it was possible to increase disease knowledge through the performance of educational activities. Clinical trial identifier: RBR-58n26h

Descriptors: Community Health Nursing; Health Education; Diabetes Mellitus; Self-Care.

\footnotetext{
${ }^{1}$ Paper extracted from Master's Dissertation "Efeito da ação educativa sobre o conhecimento da doença e o controle metabólico de pacientes com diabetes mellitus tipo 2", presented to Faculdade de Nutrição, Universidade Federal de Goiás, Brazil.

2 RN, MSc, Hospital das Clínicas, Universidade Federal de Goiás, Brazil.

${ }^{3} \mathrm{PhD}$, Professor, Faculdade de Nutrição, Universidade Federal de Goiás, Brazil.

${ }^{4}$ PhD, Professor, Faculdade de Enfermagem, Universidade Federal de Goiás, Brazil.

${ }^{5}$ PhD, Professor, Faculdade de Medicina, Universidade Federal de Goiás, Brazil.

${ }^{6}$ PhD, Professor, Escola de Música e Artes Cênicas, Universidade Federal de Goiás, Brazil.
} 


\title{
Efeito de intervenção educativa sobre o conhecimento da doença em pacientes com diabetes mellitus
}

A prevenção do diabetes e suas complicações é um desafio para a equipe de saúde. O objetivo desta pesquisa foi avaliar o efeito de ação educativa sobre o conhecimento da doença em pacientes portadores de diabetes tipo 2. Foi realizado ensaio clínico randomizado com 62 pacientes cadastrados em serviço de referência para tratamento da hipertensão arterial, no ano 2010. Os dados foram obtidos através de questionário aplicado aos grupos intervenção (GI) e controle (GC), no momento inicial e no final do estudo. O GI participou de atividades educativas em grupo, utilizando a metodologia problematizadora. Os resultados mostraram aumento significativo do conhecimento sobre diabetes nos pacientes do GI, em todas as questões $(p<0,05)$. No $G C$, algumas alterações observadas no conhecimento foram bem menores quando comparadas ao GI. Conclui-se que foi possível elevar os conhecimentos sobre a doença por meio da realização de atividades educativas. O registro clínico obteve identificador primário: RBR-58n26h

Descritores: Enfermagem em Saúde Comunitária; Educação em Saúde; Diabetes Mellitus; Autocuidado.

\section{Efectos de intervención educativa sobre el conocimiento de la enfermedad en pacientes con diabetes mellitus}

\begin{abstract}
La prevención de diabetes y sus complicaciones es un desafío para el equipo de salud. El objetivo de esta investigación fue evaluar el efecto de acción educativa sobre el conocimiento de la enfermedad en pacientes portadores de diabetes tipo 2. Fue realizado ensayo clínico aleatorizado con 62 pacientes registrados en servicio de referencia en tratamiento de la hipertensión arterial en 2010. Los datos fueron obtenidos a través de un cuestionario aplicado a los grupos Intervención (GI) y Control (GC), al inicio y al final del estudio. El GI participó de actividades educativas grupales, utilizando la metodología problematizadora. Los resultados muestran un aumento significativo del conocimiento sobre la diabetes en pacientes del GI, en todas las cuestiones $(p<0,05)$. En el GC, algunas alteraciones observadas, fueron mucho menores cuando comparadas al GI. Se concluye que fue posible elevar los conocimientos sobre la enfermedad por medio de realización de actividades educativas. Número del Registro clínico, Identificador primario: RBR-58n26h
\end{abstract}

Descriptores: Enfermería en Salud Comunitaria; Educación en Salud; Diabetes Mellitus; Autocuidado.

\section{Introduction}

Diabetes Mellitus (DM) presents a high morbidity and mortality, with significant reduction in the quality of life of patients. It is one of the major cause of kidney failure, lower limb amputations, blindness and cardiovascular disease. Therefore, prevention of diabetes and its complications has been a public health priority, however, integral care to patients with diabetes and their families remains a challenge for the healthcare team ${ }^{(1)}$. Health education is one of the strategies that can help reduce the high prevalence of complications in people with DM (2). Educating patients with DM may play a key role by encouraging to take responsibility for and supporting them in the day to day control of their condition(3).

Studies from around the world have shown the positive effects of the educational process on diabetes, with the meta-analysis ${ }^{(4)}$ finding that patients present improvements in glycemic control, and in the prevention and control of the acute and chronic complications, when they receive effective treatment, self-management support and regular monitoring. Other authors ${ }^{(2,5)}$ also suggest this alternative and they define self-care education as the process of broadening knowledge and 
skills that involve bodily, dietary, therapeutic and other practices performed by the patient, to improve metabolic control and preserve or improve the quality of life at a reasonable cost. This process incorporates the needs, goals and life experiences of people with diabetes and is guided by evidence-based standards.

The American Standardization of Diabetes SelfManagement Education (DSME) highlights the importance of the educational process based on the educational needs of the population, considering the medical history of the individual, their age, cultural influences, health beliefs and attitudes, diabetes knowledge, willingness to learn, education level, family support and financial status(2). However, there is a significant deficit of knowledge and skills in the management of the disease in $50 \%$ to $80 \%$ of individuals with diabetes and glycemic control is achieved by less than half of the patients under treatment with type 2 Diabetes Mellitus (DM2)(6-7). The great difficulty lies in finding the way to promote self-control or self-care. Thus, educational techniques have evolved over the last decade, changing didactic presentations for interventions that promote the autonomy of the patient, with their participation and collaboration ${ }^{(8-9)}$.

What is critical in choice of pedagogic health education concept is that it provides the user with the possibility of critique and the elaboration of knowledge, because only when the factors of perception and information processing are altered does learning becomes meaningful to people ${ }^{(10)}$. The problematization methodology ${ }^{(11)}$ of Freire is guided by the perception of reality, by protagonism and by working in groups. In his view, learning should be linked to awareness of a real situation experienced by the learner, in this case the patient. For Freire, teaching is not to transfer knowledge but to create opportunities for its construction ${ }^{(12-13)}$. Thus, it becomes imperative to perform work that can promote the learning of patients who have the disease and the knowledge that can influence its metabolic control. The aim of the present study was to evaluate the effect of educational actions, using pedagogic problematization methodology, on the knowledge of diabetes of patients with DM2, in a service of reference for the treatment of arterial hypertension.

\section{Method}

This randomized clinical trial was conducted between March and October 2010, in an outpatient clinic which is a reference center for the treatment of arterial hypertension. In the survey carried out for the calculation of the study sample 1000 hypertensive patients enrolled at the outpatient clinic and in routine follow-up, of both sexes were identified. Among them 279 had Diabetes
Mellitus (28\% prevalence) and of these, 47 individuals (17\%) were using insulin.

The sample was calculated from the population of 232 patients with DM2 not using insulin, margin of error of $3 \%$ of the mean of the glycated hemoglobin, with an increase of $25 \%$. A total of 76 hypertensive individuals with DM were selected and randomization was carried out, using a simple lottery, into two groups of 38 subjects: Intervention Group (IG) and Control Group (CG). The study included patients who accepted the invitation, who were not participating in another research project, who did not use insulin before or during the study and who had the physical and economic conditions to travel to the study site.

The IG participated in 12, fortnightly educational meetings over six months, each with an average duration of two hours. The IG patients who participated in at least eight educational meetings, which allowed for a maximum of four absences, were considered in the analysis. The CG patients did not participate in educational meetings, however, along with those of the IG, were accompanied in the outpatient visit routine, with consultations every three months. In the CG, four patients were excluded: one due to starting insulin therapy and three due to their failure to attend the scheduled consultations. In the IG, ten patients were excluded due to their low attendance at the meetings. Thus, 62 patients with DM2, 28 in the IG and 34 in the CG, participated in the study.

For the data collection regarding disease knowledge the Diabetes Knowledge Questionnaire(14), validated for the DM2 patient population, was used. This instrument, divided into eight topics with a total of 31 questions, was applied to all the study participants, at two times: at the beginning of the study, before any educational activity, and the end of the study. The evaluation of the knowledge was obtained from the proportion of correct answers in each topic of the survey. The value 1 was given for each correct response alternative and a total for each topic of the survey was obtained.

The educational intervention was performed in the IG with the use of pedagogic problematization methodology ${ }^{(15)}$ and its planning and organization were based on two steps: The survey of the thematic universe of the patients and the development of the educational activities. The first two educational meetings aimed to identify the learning needs and prior knowledge about the disease of the study participants. The dynamic of discussion circles $^{(15)}$ was carried out, with the aim of discovering the themes that were significant for the group. A pre-established script was used for the discussion that sought to identify what the patients knew about diabetes, the difficulties caused by the disease and their perceptions concerning what could 
help them in the treatment. The content discussed in these meetings was recorded, transcribed, interpreted and the central themes were highlighted ${ }^{(15)}$. After detailed reading of the data collected, they were subjected to exhaustive procedures, in which all the relevant words and phrases were considered, which was the moment when it was verified that the data met the aim of the study. The words and phrases most frequently registered(16) and capable of being utilized in the educational meetings were selected, grouped into thematic units and worked into situations problems at subsequent meetings.

To organize the educational activities a teaching plan was developed for each of the generative themes to be worked: the anatomy and pathophysiology of the DM; self-care: glycemic control of the DM, diet plan, physical exercise, medication; chronic complications of the DM; obesity; evaluation of self-care and quality of life. The themes were discussed with the coordination of the principal researcher who used the Technical Standards and Manuals of the Ministry of Health(1) as the theoretical reference. In each teaching plan different resources were used, such as pictures, phrases written by the patients themselves, posters, music, a trip, questions and verbal expressions of meaningful experiences. The group decoded the problem situation through means of dialogue and the reports of experiences of colleagues, seeking to comprehend the individual with DM. The points that deserved further discussion were elucidated by the coordinator, who organized the content for better conscientization of the key points, relating them to real situations experienced by the group. At the end of the activity the group was asked to verbalize solutions applicable to the reality of the participants. Through this dynamic, the GI prepared self-care measures, such as changes in behavior, adopting healthy eating habits, practicing physical activity, prevention of complications and the control of the DM, which led the group to reflection and to action, with the possibility of transforming the reality of the patients with DM.

\section{Data Analysis}

The Shapiro-Wilk normality test of the Statistical Package for the Social Sciences ${ }^{\circledR}$ (SPSS) version 15.0 was used to verify the distribution of the continuous quantitative variables. The normality of the distribution of each question was tested using the $t$ test for the parametric data and the Mann-Whitney- $U$ and Wilcoxon $W$ for nonparametric data. The quantitative variables were presented as mean and standard deviation and the categorical variables were presented as proportions.

\section{Ethical aspects}

The project was approved by the Research Ethics Committee of the Clinical Hospital of the Federal University of Goias, Brazil, under protocol No. 020/2010. All the patients who participated signed the Terms of Free Prior Informed Consent in duplicate.

\section{Results}

\section{Characterization of the study population}

A total of 62 patients completed the study, 28 in the IG and 34 in the CG. The mean age of the study population was 65.8 years $(S D \pm 10.02)$, and $75.8 \%$ were female. Table 1 shows the characteristics of the groups studied in relation to the sociodemographic variables.

Table 1 - Sociodemographic characteristics of the Intervention and Control Groups. Goiânia, GO, Brazil, 2010

\begin{tabular}{|c|c|c|c|c|c|}
\hline \multirow{2}{*}{ Variables } & \multicolumn{2}{|c|}{ IG } & \multicolumn{2}{|c|}{ CG } & \multirow[t]{2}{*}{$p$} \\
\hline & N & $\%$ & $\mathbf{N}$ & $\%$ & \\
\hline Gender & & & & & 0.128 \\
\hline Male & 4 & 14.3 & 10 & 29.4 & \\
\hline Female & 24 & 85.7 & 24 & 70.6 & \\
\hline Age (years) & & & & & $0.778^{*}$ \\
\hline Maximum & 81 & & 87 & & \\
\hline Minimum & 45 & & 44 & & \\
\hline Mean & $65.4 \pm 9.4$ & & $66.1 \pm 10.6$ & & \\
\hline Education & & & & & 0.105 \\
\hline Incomplete elementary & 20 & 71.4 & 23 & 67.6 & \\
\hline Incomplete high school & 0 & - & 1 & 2.9 & \\
\hline Complete high school & 1 & 3.6 & 1 & 2.9 & \\
\hline Incomplete further education & 1 & 3.6 & 0 & 0 & \\
\hline Did not study & 2 & 7.2 & 7 & 20.6 & \\
\hline
\end{tabular}

Values are expressed as mean \pm standard deviation or percentage. * Student's t-test. 


\section{Evaluation of the disease knowledge of the patients with DM}

At the beginning of the study, both groups presented similar knowledge when they responded to the questionnaire (Table 2). The mean percentage of total correct answers was $20.7 \%$ in the IG, with the minimum of 10 and the maximum of 37 points out of a total of 106 points (Table 2). At the end of the study, the increase in disease knowledge was significantly higher among the IG patients $(p<0.05)$. In the topic "family support", which relates to the participation of the family in the patient's treatment, there was no significant change in percentage between the groups at the end of the study.
The patients showed greater knowledge at the beginning of the study in the questions related to diet (45\%) and clinical parameters (50\%) in both groups. At the end of educational intervention, as can be seen from Table 2, the percentage increased to $78.8 \%$ and $93 \%$ respectively in the IG. In the CG the results rose to $50.0 \%$ regarding diet and decreased to $43.0 \%$ in clinical parameters. The topics that the IG participants presented less knowledge of at the beginning of the study were related to foot care $(11.5 \%)$ and hypoglycemia $(7.5 \%)$. At the end of the study, these percentages had increased considerably in the IG $(44.6 \%$ and $37.5 \%$ respectively). (Table 2 ).

Table 2 - Evaluation between the Groups of the percentage of correct answers in the Diabetes Knowledge Questionnaire at the beginning and end of the study. Goiânia, GO, Brazil, 2010

\begin{tabular}{|c|c|c|c|c|}
\hline Topics & Evaluation & Intervention Group (\%) & Control Group (\%) & $\mathrm{p}$ \\
\hline \multirow[t]{2}{*}{ General questions } & Beginning & 22.7 & 23.8 & 0.645 \\
\hline & End & 51.7 & 28.1 & 0.000 \\
\hline \multirow[t]{2}{*}{ Physical activity } & Beginning & 20.1 & 21.2 & 0.441 \\
\hline & End & 37.8 & 26.3 & 0.000 \\
\hline \multirow[t]{2}{*}{ Diet } & Beginning & 45.6 & 44.4 & 0.804 \\
\hline & End & 79.0 & 49.7 & 0.000 \\
\hline \multirow[t]{2}{*}{ Foot care } & Beginning & 11.5 & 11.5 & 0.969 \\
\hline & End & 44.8 & 17.4 & 0.000 \\
\hline \multirow[t]{2}{*}{ Clinical parameters } & Beginning & 49.4 & 49.0 & 0.888 \\
\hline & End & 93.8 & 45.1 & 0.000 \\
\hline \multirow[t]{2}{*}{ Hypoglycemia } & Beginning & 7.3 & 6.8 & 0.355 \\
\hline & End & 62.8 & 10.9 & 0.000 \\
\hline \multirow[t]{2}{*}{ Chronic complications } & Beginning & 27.7 & 27.2 & 0.807 \\
\hline & End & 62.5 & 35.7 & 0.000 \\
\hline \multirow[t]{2}{*}{ Family support } & Beginning & 16.7 & 17.6 & 0.198 \\
\hline & End & 20.2 & 18.6 & 0.307 \\
\hline \multirow[t]{2}{*}{ Total } & Beginning & 20.7 & 20.9 & 0.938 \\
\hline & End & 48.3 & 25.6 & 0.000 \\
\hline
\end{tabular}

In the intragroup evaluation regarding the responses to the questionnaire applied at the two times, there was significant improvement of knowledge in the IG in all the topics $(p<0.05)$. In the $C G$, in contrast, the scores for the items diet, clinical parameters and family support did not significantly improve (Table 3).

Table 3 - Intra-Group evaluation of the percentage of correct answers in the Diabetes Knowledge Questionnaire at the beginning and end of the study. Goiânia, GO, Brazil, 2010

\begin{tabular}{|c|c|c|c|c|c|}
\hline \multirow{2}{*}{ Knowledge about diabetes } & \multirow{2}{*}{ Evaluation } & \multicolumn{2}{|c|}{ Intervention Group } & \multicolumn{2}{|c|}{ Control Group } \\
\hline & & $\%$ correct answers & p & $\%$ correct answers & $p$ \\
\hline \multirow[t]{2}{*}{ General questions } & Beginning & 22.7 & & 23.8 & \\
\hline & End & 51.7 & 0.000 & 28.1 & 0.006 \\
\hline \multirow[t]{2}{*}{ Physical activity } & Beginning & 20.1 & & 21.2 & \\
\hline & End & 37.8 & 0.000 & 26.3 & 0.002 \\
\hline \multirow[t]{2}{*}{ Diet } & Beginning & 45.6 & & 44.4 & \\
\hline & End & 79.0 & 0.000 & 49.7 & 0.084 \\
\hline \multirow[t]{2}{*}{ Foot care } & Beginning & 11.5 & & 11.5 & \\
\hline & End & 44.8 & 0.000 & 17.4 & 0.009 \\
\hline
\end{tabular}


Table 3 - Continuation

\begin{tabular}{|c|c|c|c|c|c|}
\hline \multirow[t]{2}{*}{ Clinical parameters } & Beginning & 49.4 & & 49.0 & \\
\hline & End & 93.8 & 0.000 & 45.1 & 0.292 \\
\hline \multirow[t]{2}{*}{ Hypoglycemia } & Beginning & 7.3 & & 6.8 & \\
\hline & End & 62.8 & 0.000 & 10.9 & 0.044 \\
\hline \multirow[t]{2}{*}{ Chronic complications } & Beginning & 27.7 & & 27.2 & \\
\hline & End & 62.5 & 0.000 & 35.7 & 0.007 \\
\hline \multirow[t]{2}{*}{ Family support } & Beginning & 16.7 & & 17.6 & \\
\hline & End & 20.2 & 0.011 & 18.6 & 0.160 \\
\hline \multirow[t]{2}{*}{ Total } & Beginning & 20.7 & & 20.9 & \\
\hline & End & 48.3 & 0.000 & 25.6 & 0.000 \\
\hline
\end{tabular}

\section{Discussion}

This study sought to follow conscientization problematization methodology for the education of the diabetic patients, which generated satisfactory results with regards to the increase in disease knowledge, and the stimulation of reflections on the condition of being diabetic. This allowed the IG participants to develop selfcare measures, related to changing behavior, adopting healthy habits and practicing physical activity. These data are corroborated by another study that used this methodological approach and reported that the conscious DM patient is open to dialogue, expresses him/herself and acts as a responsible agent in the self-care process ${ }^{(17)}$.

Changes in eating behavior and the practice of physical activity in DM2 patients are very important in the evaluation of group education programs in diabetes and are subject to the improvement of knowledge and the modification of attitudes about the disease ${ }^{(18)}$. The education level can be considered a determinant factor in the effectiveness of an educational program, especially in patients with DM, who need to acquire certain knowledge to be able to develop their self-care(19). A low education level is reported as a factor that can affect adherence to the pharmacological treatment, because the drugs for the treatment of diabetes are considered complex and require comprehension of their use by the patients(20). The two groups, IG and CG, were found to be homogeneous in relation to education, as $66.7 \%$ and $67.6 \%$ of the participants respectively, had incomplete primary education, which enabled the comparison of learning between them. Other studies also found a predominance of this education level in patients with $\mathrm{DM}^{(6,19)}$. The advanced age found in this population did not represent difficulties in learning, a different result than was found in a study that examined the barriers to diabetes education and concluded that older people, among other difficulties, also present limitations in education ${ }^{(9)}$.

The educational program implemented in this study increased the knowledge of diabetes of the IG patients in all the topics analyzed. Other studies that have developed group educational programs for patients with DM, using participatory teaching strategies, such as role plays, relating of experiences and walking, also found an increase in knowledge about the disease ${ }^{(6,19)}$. A review carried out with 72 studies on DM2 self-management education with follow up periods of between six to 12 months found positive results regarding understanding the disease and concluded that educational interventions that involve the collaboration of the patients may be more effective ${ }^{(21)}$.

The availability of knowledge and the strengthening of active attitudes in relation to the disease, directed toward the person with diabetes and their family, through educational health practices, has been linked to the prevention of complications through self-management of the disease, which enables a person to exist better with their condition ${ }^{(2)}$. Current health education practices recognize the importance of new teaching strategies that valorize the autonomy of people with diabetes and promote the taking of conscious decisions, making them self-managers of their health ${ }^{(22)}$. These are the goals of education for empowerment, which uses an interactive approach through the strategy of solving problems inspired by the contributions of Freire, applied in health education since the start of the $1990 s^{(5)}$.

The dialogism, the reports of experiences of the group and the reflections regarding their own acts were an effective way to create the possibility of adherence to a new lifestyles and the development and acquisition of selfcare attitudes for the DM patient. There is evidence that knowledge about the characteristics and complications of diabetes greatly improves the evolution of the disease, because it leads to early detection and to a reduction in the rate of installation of chronic complications ${ }^{(23)}$. In this study, the IG obtained a higher increase of knowledge in the topics: general aspects of the disease; foot care; hypoglycemia; and chronic complications. Knowledge about the disease is the basis for the development of self-care actions in diabetes, although the acquisition of knowledge does not necessarily translate into a change in behavior. The lifestyle and beliefs may also have a strong 
influence ${ }^{(4,17-18)}$. To increase the knowledge of individuals with DM seems to be essential for reinforcing their ability and confidence to develop self-care actions, which together contribute to better disease management ${ }^{(24)}$.

Family support has been described as an essential factor for stimulating the self-care of patients with $\mathrm{DM}^{(25)}$. In this study, family participation in the educational activities was encouraged. The change in this topic, although significant in the IG, was small in the intragroups comparison and did not have the same behavior as the other topics where the change was significant. To achieve family interaction in any educational process that occurs outside the home environment is a challenge. It is unusual for family members to monitor and be involved in the care of diabetic individuals. The main limitation of this study was the reduction of the sample size in relation to the initial calculation. However, it was possible to identify significant changes in the behavior of the different groups.

\section{Conclusions}

In this study, despite the initial lack of knowledge encountered in the study population, it was possible to increase their knowledge about diabetes mellitus. The educational activities carried out using conscientization problematization methodology encouraged the participation of the group and fostered learning. The working in groups method used in this study was shown to be a feasible and appropriate strategy for the development of educational activities, which can help to promote the autonomy of the patients and enable the active participation of the subjects in the construction of new knowledge.

The implementation of a structured program of care for the chronic diseases, which increases the efforts to perform educational strategies with proactive approaches and the participation of the patients in all the phases of planning, development and implementation of the educational activities, could be the basis for preventive interventions and for health promotion. In an active education proposal, the person with DM should be the main subject and the health professional a facilitator of learning that stimulates the potential and the ability to reinvent reality in people, achieving the production of their health. This work shows that the individual with Diabetes may be co-responsible for their health and that their recovery is conditional on their active participation.

\section{Acknowledgement}

We acknowledge endocrinologist Luciana Muniz Sanches Jardim for their collaboration in the planning of this research.

\section{References}

1. Ministério da Saúde (BR). Cadernos de atenção básica: diabetes mellitus. Brasília (DF): Ministério da Saúde; 2006. 56 p. (Série A. Normas e manuais Técnicos, n. 16). 2. Funnell MM, Brown TL, Childs BP, Haas L, Hosey GM, Jensen $B$, et al. National Standards for Diabetes SelfManagement Education. Diabetes Care. 2008;31(1):12-54. 3. Davies MJ, Heller S, Skinner TC, Campbell MJ, Carey ME, Cradock $S$, et al. Effectiveness of the diabetes education and self management for ongoing and newly diagnosed (DESMOND) programme for people with newly diagnosed type 2 diabetes: cluster randomised controlled trial. $\mathrm{Br}$ Med J. 2008;336(7642):1-11.

4. Jarvis J, Skinner TC, Carey ME, Davies MJ. How can structured self-management patient education improve outcomes in people with type 2 diabetes?. Diabetes Obesity Metabolism. 2010;12(1):12-9.

5. Ciryno AP, Schraiber LB, Teixeira RR. Education for Type 2 Diabetes Mellitus Self-care: from compliance to empowerment. Interface Comunicação Saúde Educ. 2009;13(30):93-106.

6. Otero LM, Zanetti ML, Ogrizio MD. Knowledge of diabetic patients about their disease before and after implementing a diabetes education program. Rev. LatinoAm. Enfermagem. 2008;16(2):231-7.

7. Sociedade Brasileira de Diabetes (SBD). Diretrizes da sociedade brasileira de diabetes 2007: tratamento e acompanhamento do diabetes mellitus. São Paulo; 2007.

8. Norris SL, Lau J, Smith SJ, Schmid CH, Engelgau MM. Sef-management education for adults with type 2 diabetes: a meta-analysis of the effect on glycemic control. Diabetes Care. 2002;25(7):1159-71.

9. Rhee MK, Cook CB, EL-Kebi I, Lyles RH, Dunbar VG, Panayioto RM, et al. Barriers to diabetes education in urban patients: perceptions, patterns, and associated factors. Diabetes Educ. 2005;31(3):410-7.

10. Leite MMJ, Prado C, Peres HC. Educação em saúde: desafios para uma prática inovadora. São Caetano do Sul: Difusão; 2010.87 p.

11. Bordenave JD, Pereira AM. Estratégia de ensinoaprendizagem. 24a. ed. Petrópolis: Vozes; 2002. 312 p.

12. Freire P. Pedagogia da autonomia: saberes necessários à prática educativa. 25a. ed. Rio de Janeiro: Paz e Terra; 2002. 54 p.

13. Freire P. Conscientização: teoria e prática da libertação. Uma introdução ao pensamento de Paulo Freire. 3a. ed. São Paulo: Moraes; 1980.87 p.

14. Otero LM. Implementação e avaliação de atendimento ao paciente diabético utilizando o Protocolo Staged Diabetes Management. [Tese de doutorado]. Ribeirão Preto (SP): Escola de Enfermagem de Ribeirão Preto da Universidade de São Paulo; 2005. 197 p. 
15. Freire P. Educação como Prática de Liberdade. 19a. ed. Rio de Janeiro: Paz e Terra; 1989. 150 p.

16. Bardin L. Análise de conteúdo. Lisboa: Edições 70; 2009. 288 p.

17. Rêgo MAB, Nakatani AYK, Bachion MM. Educação para a saúde como estratégia de intervenção de enfermagem às pessoas portadoras de diabetes. Rev Gaúcha Enferm. 2006;27(1):60-70.

18. Torres HC, Franco LJ, Stradioto MA, Hortale VA, Schall VT. Avaliação estratégica de educação em grupo e individual no programa educativo em diabetes. Rev Saúde Pública. 2009;43(2):291-8.

19. Miyar LO. Impact of a health promotion program carried out by nursing among type 2 diabetes patients, within the community. Rev. Latino-Am. Enfermagem. 2003;11(6):713-9.

20. Pace $A E$, Ochoa-Vigo K, Caliri MHL, Fernandes APM. Knowledge on diabetes mellitus in the self care process. Rev. Latino-Am. Enfermagem. 2006;14(5):728-34.

21. Norris SL, Engelgau MM, Narayan KMV. Effectiveness of self-management training in type 2 diabetes. Diabetes Care. 2001;24(3):561-87.

22. Funnell MM, Anderson RM. Empowerment and SelfManagement of Diabetes. Clin Diabetes. 2004;22(3): 123-7.

23. Silva $C A B$. A educação no tratamento das doenças crônico-degenerativas. Rev Bras Promoção Saúde. 2006;19(4):195-6.

24. Sousa VD, Zauszniewski JA. Toward a theory of diabetes self-care management. J Theory Construct Test. 2005;9(2):61-7.

25. Santos ECB, Zanetti ML, Otero LM, Santos MA. Care according to diabetes patients and their main caregivers. Rev. Latino-Am. Enfermagem. 2005;13(3):397-406. 